\title{
Ministerial formation policies of the Northern Theological Seminary of the Uniting Reformed Church in Southern Africa: Looking through the eye of a needle
}

\author{
Kgatla, ST \\ University of Pretoria, Pretoria, South Africa \\ kgatla@up.ac.za
}

\begin{abstract}
This article investigates the theoretical and practical effectiveness of the Uniting Reformed Church in Southern Africa's (URCSA) ministerial formation of the Northern Synod. The URCSA is part of the Reformed Movement (Calvinism) that was established by the Dutch Reformed Church (DRC) of South Africa that mainly came from the Netherlands to establish itself in South Africa and later established ethnic churches called daughter churches into existence in terms of a racially designed formula. After many years of the Dutch Reformed Church missionary dominance, the URCSA constituted its first synod in 1994 after the demise of apartheid. It was only after this synod that the URCSA through its ministerial formation tried to shake off the legacy of colonial paternalism and repositioned itself to serve its members; however, it fell victim to new ideological trappings. This article is based on a study that traces some basic Reformed practices and how the URCSA Theological Seminary of the Northern Synod dealt or failed to deal with them in its quest for the ideal theological ministerial formation.
\end{abstract}

Keys words

Calvinism; ministerial formation; policy; Reformed tradition;

Uniting Reformed Church in Southern Africa

\section{Calvinism came to South Africa packaged in the Western culture, language and idiom}

The Reformed Tradition (Calvinism) was brought to South Africa mainly through the work of the Dutch Reformed Church (DRC) in $16^{\text {th }}$ 
century when the Dutch East India Company established a foot in the Cape of Good Hope (Elphick 2012:1). It was through the Dutch officers and clergymen who made sporadic evangelization of the Khoisan people. Later as the settlers became aware of the need to evangelise the indigenous people, pioneering missionaries were sent to hinterland. The primary aim of the DRC missionaries was to propagate the Reformed Protestant Theology and convert their subjects to their religion. They, however, could not escape Western paraphernalia, and wittingly and unwittingly warped it with a domineering Western paternalism enacted upon African people. According to Cronje (1982) and Saayman (2007), from the start the DRC missionaries were reluctant to do missionary work among black people until they saw the progress by other foreign missionary societies in the Cape colony. The reason for reluctance was racial disdain of black people in the Cape Colony occasioned by white supremacy (Elphick 2012:218).

When they (DRC) started with the missionary work two hundred years after their arrival (Saayman 2007:20), they converted (proselytised) the African people into their religion through the means of instruction (catechism, person-to-person interaction, preaching and church discipline) (Assimeng 1986:7) without much appreciation of African worldviews and epistemologies (Elphick 2012:223). The African worldviews and religions were seen as heathenism and needed to be conquered and replaced with a "civilised Christian worldview" (Van Rinsum 2001:11). The missionaries were convinced and operated along the basis that the only way the black people could be civilised was through the teaching of the Gospel (Bosch 1991:296) and church discipline (Kgatla 1988:88). For this reason, Du Plessis, who played a pivotal role in shaping the DRC's missiological paradigm in the late 1920s (in Elphick 2012:225-227), would issue a warning against hastily ordaining black clergy and surrendering their (white) control to black people too prematurely. The autonomy of black congregations under the leadership of black leaders would only be granted once the "Bantu Independent States" within the borders of South Africa were established in terms of the Bantu Administration Act of 1971 (Act No 21 of 1971) and they have attained self-governing status (Changuion \& Steenkamp 2012:221). Within the policy of the DRC any deviation to the rule of granting leadership autonomy within their congregation would be vetoed by the Synodical Mission Commission (Elphick 2012:45). 
On the mission front, the primary means of making converts was through the communication of the missionaries' languages - although black interpreters were used (Kirkalby 2005:37). Gospel tracts about basic teaching of Christian religion were produced and used together with extracts from the Bible, translated into the indigenous languages and used as instructional materials (Kgatla 1988:20). Religious instructors were employed for that purpose (Cronje 1982:63). The next logical level in the establishment of Western superiority and propagation of missionary religion was by means of mission schools (Elphick 2012:227) although they were later taken over by the government with introduction of Bantu Education in the early 1950s. Theological education at home, church and Bible schools (seminaries) were introduced to the families of their converts. The church workers, evangelists and later black ministers were appointed (Crafford 1982:327). But the theological education and congregational control remained under the white missionary for a long time, even when the black church had introduced ministerial formation centres to train black ministers who became ministers and evangelists among their own people. The threat missionaries perceived in black people, as time went on, was that they were developing a nationalism of their own which led to their "independent political thinking, embodiment of white materialism, [and] socialism" and were further exposed to new ideas of liberty, equality, and fraternity of which white DRC missionaries did not approve (Elphick 2012:230). For that reason, missionaries were to ensure that educated black leaders had to remain under their influence (Elphick 2012:231) and control. Although black evangelists and ministers were sent out to assist in the conversion of their black people as well as the furtherance of the missionary religion among their people, missionaries did not release their grip on the black mind (Du Toit 2009:3). The approach to their missionary enterprise was paternalistic and condescending and the missionaries were far from reading the signs of time of black resistance. Theological training remained under their control until very late.

\section{Reformed tradition within the URCSA}

The Reformed legacy within the URCSA is found in its church polity which is expressed in the church order, synod acts, confessions, hymnals, liturgical and teaching manuals and other policy documents as espousing Calvin 
philosophy. From the church order, which is the supreme constitution of the church, the church polity (how God rules over His church through people), synod acts and teaching manuals for URCSA, seminaries are fully entrenched as members of the Reformed church. The spirit of URCSA's church order is liberating and empowering. Liberative education aimed at freeing persons and societies, so that they can live more fully, should be the essence of the true theological agenda (Moore 1991:163).

The URCSA ministerial formation evolved from and was informed by the decisions of the founding URCSA General Synod of 1994 and subsequent synods (Kritzinger 2010:211). Before 1994 the ministerial formation of both the Dutch Reformed Mission Church (DRMC) and the Dutch Reformed Church in Africa (DRCA) was under the influence of the (white) DRC. The main sources for URCSA mission policy from which the policy could be understood are the acts of the first five synods and the article on ministerial formation praxis by Kritzinger, which was published in the August 2010 Missionalia. Any authentic evaluation of URCSA NTS policy for ministerial formation cannot ignore these documents. In his article, Kritzinger (2010:212) sees the proposal taken by the URCSA at its first synod in 1994 as a break with the DRC as far as ministerial formation is concerned. Kritzinger (2010:212) sees this as an appropriate and constructive decision for it represents an epistemological break in the life of the URCSA. According to Kritzinger (2010:212), the new ministerial formation became "holistic", as it included three dimensions of intellectual (theological) insight, practical (ministry) skills, and personal, spiritual growth. The previous ministerial formation under the DRC did not espouse unity, justice and equality and it was paternalistic (Kritzinger 2010:214). However, Kritzinger (2010:214) hastens to state that the establishment of the URCSA ministerial formation was not in opposition to the DRC, but that URCSA was compelled by the Belhar Confession that edged members of the URCSA to seek unity, reconciliation and justice. But continual financial and resource constraints kept haunting the URCSA in its search for true autonomy on ministerial formation.

The third General Synod of the URCSA (2005) further adopted the process of equipping URCSA church members with a view of ordination for ministry as "ministerial formation". The concept of "ministerial formation" was, however, not new within the URCSA, for it had already been debated 
since the inception of the church. In 1985, for example, the Latin American theologians were grappling with a name for theological training. Names such as Ministerial Preparation, Ministerial Formation, Theological Education, Ministerial Training, Theological Education by Extension, were used at the 1985 Latin American Consultation under the auspices of the Latin American Fraternity (Padilla 1986:1). It is for the reasons above that a deeper scrutiny of the URCSA NTS policy for ministerial formation is scrutinised hereafter.

It is the contention of the author of this article that any meaningful assessment of the theory and practice of the Reformed (missionaries) teaching into the life of African people ought to include theological education $^{1}$ as it was the gateway into African customs and beliefs. The aim is also to establish to what extent the Uniting Reformed Church in South Africa (URCSA), especially the Northern Theological Seminary (NTS) ministerial formation, has "rinsed itself from apartheid stains" and has stopped a veritable "colonization of brother by brother or liberal white compatriots" (Fanon 1963:61). As was stated earlier about the colonial history of South Africa, education became the site for the struggle leading to the 1976 Soweto students' uprising (led by the South African Student Movement under the influence of the Black Consciousness). Education was not only seen by the white establishment in South Africa as an authentic vehicle of "colonizing" the mind of black people (Du Toit 2009:3), but also was a means of retarding their development to prevent them from reaching the level of white people, and therefore constituted a threat to their policy of separateness. Black people had to have an education that would not allow them to envy white education (Worden 2012:105) and "think white" (sic).

The article is trying to establish the trajectory of theological education within the URCSA and to argue that the vicissitudes of exclusion and misrepresentation of the past have not been altogether removed from the theory and practice of the NTS ministerial formation. In some respects,

1 For the purposes of this study the concepts of theological education and ministerial formation are used interchangeably. The author is aware that theological education is broader and includes Christian education from infant stage to adult stage in order to prepare Christian people, laity and professionals, for the work of God (Wills \& Welker 1999:5). 
the dehumanising conditions are still self-evidently inherited from the colonized and practiced by "black on black" (Ilunga 1984:7).

\section{Ministerial formation at NTS falls short of reaching its aim}

The article wants to validate the theoretical evidence with empirical findings from the interviews conducted with ten ministers of the URCSA from the Northern Synod. The URCSA spans the period from 1994 to the present when two DRC "daughter" churches were established: the Dutch Reformed Mission Church and the Dutch Reformed Church in Africa (Kritzinger 2010:212). The extent to which the ministerial formation training taught at the NTS is successful should resonate with the life experience of the ministers and be affirmed by the ordinary members. For any meaningful transformation from the past to the present to be achieved, the NTS should avoid any complacency now that the ministerial formation is under their supervision and not anymore under DRC missionaries. However, there are new theological pitfalls that were not there before such as tyrannical tendencies from some of the leaders coupled with a sense of theological bankruptcy (Kgatla 2019: 158). For this reason, the theological programmes followed at the NTS should orient themselves intentionally in terms of serving the Christian community (Ferris 1990:141) and not being geared towards self-gratification and grandstanding. Parallel development between ministry formation and the practice in the congregations are counter-productive. If the two lines cannot meet, then all theological efforts are done in futility. The authentic ministerial formation should be premised on reciprocity, relevance, respect, humility, consultation, reflexivity and true compassion. The clergy's input (from congregations) into the running and training of future ministers should be enlisted for the ministerial formation to be relevant and purpose-driven. Much as the dominant opening logo to the Freedom Charter reads the "people shall govern", the URCSA motto should read the "people shall make their own disciples". Ela (1994:145) warned some two decades ago that church leaders should renounce religious discourse pronounced from high. Any meaningful ministerial formation should enable people to find their way of speaking of God even where they face the forces of death and destruction in their lives. For them to cross the bridge towards decolonization of the mind they need theological training that is transformative, well-grounded, 
premised in liberative discourse and free from complacency. African people should be enabled by going through mental metamorphoses and stop behaving as if they were "created with leftovers of the dust that God used to create the first human beings" (Magesa 1976:19).

A caution should be heeded here that theological education is not necessarily done to increase the "faith" of the students as Calian (2002) brilliantly cautions. Instead, theological education is done in order to provide students with information, an interpretative point of view, practical skills, and an increased enthusiasm to become life-long students of scripture (Calian 2002:98). The learning process neither begins nor ends with going to the seminary. The chief objective of seminary education should be to empower the learner and the community for a better life of faith and fight against inequality and oppression. No effort should be spared to have a ministerial formation that is visionary and determined to produce credible leaders that bring authentic change in the lives of others. Theological education that is responsive to the need of the poor and the marginalized and at the same time self-critical and guarding against self-entitlement is crucial.

The contents of what is taught at NTS should equip "would-be ministers" to meet the needs of the recipients and resonate with what they believe. The needs of African people in South Africa include the ability to discern the proliferation of occults that give false promises to people who are plunged in abject poverty, extreme inequalities and corrosive social violence (Kgatla 2018). This should be the goal and objectives of the Reformed teachings in the world (Costas 1986:3) as articulated in the Belhar Confession (1986).

The triangular golden thread that moves from the NTS to the serving ministers, to the ordinary members and back to the NTS (for evaluation and modification of their programmes) should be visible and empowering, and affirmed by all those who are involved in it. The ministerial formation should be able to reach all levels of the community as well as the wider society with its liberating theological nuances. In a country where the majority of the citizens were intentionally subjected to slave-inducing programmes, the church should rise to the occasion and pay special attention to workers, peasants, the marginalised and the oppressed to discover the liberating God in their circumstances (Grzelak \& Kinunda 2016). It is not enough to bemoan the past. Instead, it is crucially important to shape a better future 
for all. As Karl Max said, “The philosophers have only interpreted the world, in various ways, the point, however, is to change it" (Murphy 2013). In responding to this philosophical insight, by reshaping and refocusing the NTS programmes, every believer should be taken seriously, as a Reformed adage conceptualises it, as "the priesthood of all believers" (Wilhoit 2000:17). All members in various congregations are called to ministry (Calian 2002:85); however, we should hasten to issue a stern warning that not every believer is a candidate for ministry, as it is the practice at this stage where every applicant is regarded as suitable for the ministry at NTS. Both the congregations and the NTS should agree on the admissibility and non-admissibility of candidates for the ministry. Unfortunately, some candidates apply to study for ministry because they have no other place to go and admission to study at the ministry has been guaranteed, so to speak "before they were born". Any admission of students to study for ministry without critical scrutiny may prove to be detrimental to the rest of the URCSA. The ministerial formation should also serve as a means to ensure that the chaff does not mix with the wheat. The ideology of self-entitlement should be resisted. In article 11.2.2 of the booklet Manual for Ministerial Formation, under the heading "Academic formation", mention is made that the Regional Curatorium develops the relationship with the participating institutions of higher learning mentioned in article 9.2, and sees to it that students grow into mature and well-rounded contextual theologians. But from the interviews with all respondents it was established that the ties between NTS and tertiary institutions is amorphous and could not be defined. Institutions of higher learning follow their own rationalization curricula (Naidoo 2012) to which the NTS should supplement them with their own in-house courses. But the NTS has no staff to fulfil that need and effectively nothing tangible is done.

\section{From colonialization of education to metacolonialisation of education}

Somalian scholar Hussein Bulhan (2015) maps a way for the decolonized education by tracing how Africans were colonized both psychologically and materially. He traces the process that led to the acquisition of their land by colonial powers which went hand in hand with the colonization of their very being. Although the African countries are now decolonized 
there is still the condition of metacolonialism (coloniality) where the neocolonialization manifestations are still felt. According to Bulhan (2015) education that does not focus on changing passive victims into selfdetermining actors, from top-down approaches to context-sensitive, and from Eurocentric epistemologies to African self-driven insights, is still locked in coloniality. In this respect Longeway (1990:1-20) warns against the rationality of escapism, which he calls self-deception. The purpose of coloniality in post-colonial Africa is to draw Africans away from their everyday troubles and sometimes even to make them fantasise about being better off than they are really are. For this reason, Africans should first understand the history of colonialism - the precedents instigating it, its underlying motivations, the various stages it had gone and the consequences that followed (Bulhan 2015). Unless the Africans develop the concept of agency that redefines and acts as the underside of history to make their choices and freely implement them then their road to liberative education remains a tantalising mirage. They should be able to question the status quo and conscientiously create and implement their new reality without fear (Molosi \& Dipholo 2016:55). The responsive education should identify plethora of Western paraphernalia and images embedded in colonialism, cultural superiority, altruism, coercion, and imperial expansion, which eventually colonised the African mind (Ngugi wa Thiong'o 1986:384) to the point of their social enslavement. In the same vein, Biko (2004:164) attests that the starting point of the process of decolonisation (education) has to do with diminishing fear in black minds. Fear of pain, even death, is an impediment to real liberation (education), according to Biko (2004:164).

\section{Theoretical and methodological framework}

This article is guided by the cognitive consistency theory model. On a small scale, the article examines the inconsistencies between what is contained in URCSA's ministerial formation policies and manuals and the actual practice among ministers and congregations. It is postulated that there will be tension between the ministerial formation and congregations if there are differences between the policies and the praxis. Consistency holds people together, but inconsistency brings about dissonance and confusion (Hart \& Mas-Colell 1989:589-614). In contrast, normality and equilibrium bring healthy relationships. Thus, in the world of faith communities, it is 
important that individuals are able to control their lives by experiencing certain consistencies. The metaphor "the right hand should know what the left hand is doing" is fitting here. If what is in the manuals and policies of URCSA NTS is not what ministers and congregations expect, teach and experience, there will be tensions between the parties. The inconsistencies should be eliminated and replaced by authentic shared values. Authentic purpose and vision should be guiding principles. The classical example here is the claim of networks (Article 9.1.3 of the Manual) of URCSA congregations and ministers who work as mentors for theological students and yet none of respondents in the fieldwork was aware of the existence of such structures. Again article 10 mentions the Board of Lecturers which respondents were not aware of its existence. Articles in the Manual for Ministerial Formation are beautifully put, but in essence they are no such things in practice.

As already stated, the purpose of the article is to pinpoint the discrepancies that exist between what is taught at the NTS ministerial formation centre (or in its policies and manuals) and what the ministers in the congregations are expressing. From repeated concerns espoused by the clergy in the congregations, there seems to be a gap between what is taught at the seminary and what is preached in congregations (Respondents 1-10). A robust study of this nature that exposes the gaps and contradictions that exist between the NTS and the serving ministers has not been done before. The primary aim of the study, therefore, is to investigate and ascertain the extent to which the accountability to congregations is still holding among the members of NTS and to determine the cause of the decline, if there is any. Where possible, recommendations will be made to arrest the situation if it is necessary. Furthermore, the study wishes to establish whether the leaders of the ministerial formation centre are aware of the problems in congregations, and what they are doing to attend to them.

\section{Qualitative data gathering and analyses}

Qualitative non-probability convenient sampling was conducted on some of the practicing URCSA ministers. A number of questions on what the ministers perceive as NTS practice were posed and responses were encoded through the telephone interview. The study followed qualitative data 
gathering and analysis. Subsequently the data gathered through interview was transcribed, interrogated to gain detailed insights into the views of ministers and developed a data coding system; linking units of data to form overarching patterns which could lead to the development of theory (Noble \& Smith 2013). Recurring themes were methodically identified to provide description of what the respondents saw as overarching inadequacies in NTS ministerial formation.

During the information gathering stage of the study, respondents were asked questions from a questionnaire over the telephone. Clarification was given where participants experienced difficulties. The study took a qualitative approach and general way of thinking about grounded theory research. The value with grounded theory research is that it describes, either explicitly or implicitly, the purpose of the data collection, how the data is collected, the role of the researcher(s), the stages of research, and the method of data analysis. After the interviews, tables were used to categorise data for assessment or evaluation. No statistical evaluations were employed but a few responses from the telephone interviews were analysed and interpreted and conclusions were made.

\section{Over simplistic assumptions implied in URCSA NTS policy for ministerial formation}

The following assumptions can be detected in the URCSA NTS ministerial policy as presented by its chairperson and leader Kritzinger in an article published in Missionalia under the heading: "Ministerial formation praxis in the Uniting Reformed Church in Southern Africa: In search of inclusion and authenticity" in 2010.

\section{Authentic and credible ministerial formation needed}

The demise of the Stofberg Theological Seminary after the departure of white DRC lecturers should not be underplayed, especially as it is mentioned as being one of the defining moments of the URCSA NTS ministerial formation policy. African (black) leadership that took over from the white lecturers needs to be scrutinised, and the reasons why they could not succeed must be established. According to Kritzinger (2010:216), much was learnt from the failures of Stofberg's leadership from 1995 to 1999 
without giving details of the causes of their failures. Unless the causes of the problems are mentioned and attended to, their consequences will keep haunting the church. As much as the DRC policy on theological training for blacks was problematic, black leadership had its own problems that need to be faced squarely. Human failures and problems manifest themselves in a variety of ways and everywhere. Selective blaming and one-sided critics are not going to help the URCSA NTS ministerial formation emerge as an authentic and credible ministerial formation.

\section{Language policy in education}

The problems of language policy in higher education institutions in South Africa are daunting ones. None of the institutions of higher learning in South Africa have come up with a working and tangible solution to the language challenges facing them. South Africa has eleven official languages which are protected by the constitution (Ministry of Education 2002:5-15). As Foley (2004:58) puts it: "from [a] theoretical point of view, it is possible to develop all eleven languages, but from a practical perspective it is not going to happen". To develop both learners and teachers to master a language and be able to give instruction in it has enormous financial implications (Foley 2004:61). The cost of translating materials into the indigenous language is not only costly but near impossible, for the present government has more demands for money such as the \#feesmustfall movement and it is unlikely that it would generate money to develop indigenous languages as media of instruction. Kritzinger (2010:219) suggests that a one-year course in an indigenous language other than one's mother tongue could be a solution, but this would be a cosmetic solution rather than an attempt to address the policy of multilingualism at higher learning. A one-year course in an indigenous language cannot qualify one to be competent in that particular language. Various universities in the country tried to adopt one local language in their area to be paired with English or Afrikaans as an attempt to comply with language policy imperatives but due to state funding they could not succeed in this arrangement. It will be mere speculation to try to address the demands of national language issues without first getting the house in order. 


\section{Vested sublimed interests}

State-funded universities have a definite role to play in the communities. Their intellectual, philosophical, psychological and sociological contributions as envisaged in the field of humanities are given. But the theological denominational programmes may be difficult to cater for in the university-church relationship (Cannell 2006:102). Although students should benefit from rigorous academic freedom through the interaction with state-funded universities to become "balanced prophets" (Calian 2002:27) and avoid the danger of post-modernism, the URCSA NTS ministerial formation is still unable to register its presence in the situation. In the materialistic world the rich dictate the agenda and the poor are compelled to follow. The NTS is caught up in this situation.

\section{Serving ministers as mentors to ministry students}

A questionnaire was distributed among serving ministers to ascertain whether they are involved as mentors for the ministry students. They all said that they did not perceive themselves as mentors to the ministry students. Ministers and elders who are not aware of the policy and agenda of the URCSA NTS policy cannot be said to be playing a key role in ministerial formation. Ministers who participated in the research categorically deny that they are aware of the in-house courses where they are called upon to come and strengthen the confessional identity of students. The URCSA NTS policy for ministerial formation as presented in the article by Kritzinger (2010) does not represent the true state of affairs in the Northern Synod.

\section{Research findings and analysis}

Ten respondents were interviewed. The questionnaire consisted of openended and closed-ended questions. It was administered over the phone and the respondents were given the opportunity to seek clarity where questions were ambiguous. Almost all questions were fully answered. The closed-ended questions included biographical information, the highest tertiary qualification obtained, the year of ordination and how many years the respondents have been in the service as well as the number of congregations they have served. A Likert scale of evaluation was also administered to serve as a control to the open and closed-ended questions. 
One had to include the Likert scale of evaluation in order to collaborate the respondent's reaction to the questionnaire and determine whether there are resemblances between the two.

\section{URCSA's use of their knowledge, skills and experience}

Respondents were asked whether the URCSA, being at congregational or synod level, is using their knowledge, skills and experience. The question was intended to measure the relationships and perceptions between various stakeholders. To this question eight respondents said that URCSA is not using their knowledge, skills and experiences. One respondent said that URCSA is using his/her knowledge, skills and experience while the other respondent did not answer the question. When asked what the reasons were for the exclusion, seven out of ten respondents blamed the problem on a power struggle in the church. Leaders are afraid of the challenges they might impose on them in order to protect their positions; some said leadership has its own faction (grouping). Nepotism, deliberate exclusion and excessive use of power are said to be at the centre of the leadership administration. More energy is used in discrediting one another with the aim of building one's empire or legacy. Church order and confession that should help the church members to regulate their behaviour are relegated to mere documents without any substance. The same culture is said to be dovetailing down to the church councils where ministers are relegated to serve sacraments but are not involved in church administration.

In response to the question on how the leaders can regain respect and trust from the members, many different suggestions were made. The first respondent suggested that they should have a heart for the people and the second respondent said that they should be visionary, creative and motivated in their work. The third respondent indicated the need for reciprocity in leadership instead of a top-down approach, while the fourth suggested training in leadership. The fifth respondent pleaded for the equal treatment of all congregations while the sixth came up with the idea of involving all congregations. The seventh respondent pointed to the need of the pastoral letter as an effective means of communication. The eighth respondent highlighted the importance of respect, consultation, involvement and collectivity. The transformation of tradition and innovation were the points 
suggested by the ninth respondent while the tenth respondent suggested that the leadership should speak with one voice.

Respondents were asked what the average qualifications of their members were. Five said that they had a Grade 12 certificate, two replied and said that they had an undergraduate degree, one respondent completed Grade 8 (standard six) while another said they have never attended formal schooling. However, when asked how they could be taught the Reformed teachings so that they may live by them, all agreed that they are capable of being taught. They are capable of receiving good education provided it is based on good methodology and it is done from the heart (with all sincerity). Out of the respondents, eighty percent mentioned Bible studies, workshops, seminars and good contextual sermons as ideal methods of teaching their members. The education should be contextual and address contemporary issues. They further stated that these methods should be done on an ongoing basis. One respondent was more despondent and argued that the entire church should be re-educated, starting from catechism class using vernacular language. According to this respondent, the situation needs rigorous overhauling.

When respondents were requested to be specific about how the members of their congregation should be nourished theologically, some repeated the answers that they had provided in the previous question. Some suggested down-to-earth projects, sermons that are relevant to the situation, outcomebased preaching and one respondent suggested that all members should obtain a compulsory one-year certificate in theology from a university. Therefore, all of these responses are pointing to a very serious condition that needs earnest and immediate attention. Both the church leadership and ministry for Christian education should review their current programmes and channel their energy, resources and skills to where they are needed the most. The warning bells that the URCSA is embroiled in a power struggle, factionalism, nepotism and a self-serving agenda should not only be taken very seriously but should also signal necessary self-introspection that must be done for the service of God's kingdom. 


\section{Awareness of the policies that govern URCSA ministerial formation}

The underlining hypothesis pursued in this article is that the teaching and the ministerial formation policies followed at the NTS are not commensurable with the knowledge and experiences of URCSA serving ministers. For this reason, some direct questions were directed to the respondents to establish their awareness of the policies.

\section{Awareness of the policies that govern URCSA ministerial formation}

This question was posed with the awareness of Kritzinger's allegation that these policies are submitted to the decision-making General Synod and are approved and enacted into the URCSA statute (2010). According to Kritzinger, a ministerial formation task team proposes policies that include regulations on the management of the seminary, disciplinary measures for the students, duration of the study, the content of the curriculum, the relationships that regulate universities and the seminary, and manuals on ministerial formation, which include profiles of ministers, and all clauses that form the constitution of NTS. These submissions are made during the full sitting of the synod and in the presence of all ministers and an equal number of elders from each congregation (in the case of the regional synod) and minister and elder delegates from the Presbytery (in case of the General Synod). An argument may be raised that those who have attended the synod have no excuse that they are not aware of the policies governing the URCSA ministerial formation. I will refute these claims as unfair and misplaced within sound, accountable and authentic Christian leadership in the conclusion.

Three of the respondents indicated that they were aware of the policies that govern URCSA ministerial formation and went further to explain how they became aware of them. They are serving on the ministerial formation task team and that is how they became aware of them. They did not become aware of them because they were submitted and discussed at the synod or were explained to them. One respondent added that he/she became aware of the policies because he/she took the initiative of searching for them and becoming familiar with them. Seven respondents replied and stated that they were not aware of the policies because there is no communication or 
link with the NTS. What was communicated to them was the requests for fund-raising events such as the gala dinner and other special fund-raising. They further said that no one from the seminary ever visited them to explain anything concerning the training of students or any of the policies. Respondents should not be blamed for their ignorance and negligence about the contact or communication between NTS and ministers and congregations as it should be stated that it is in the best interest of the NTS for the serving ministers to know about the policies that govern their training for the purposes of support if anything is requested from them. If both regional and general synods are unable to reach the congregations and ministers, someone should make an effort to do that. However, NTS is responsible for this not because of its strategic position but because of the nature of its work.

\section{Use of Likert scale of evaluation}

Using the Likert scale, the researcher phrased the same questions on the non-existence of a relationship between NTS and the congregations and ministers. The statement: "The ministerial formation is planned by NTS without consultation with the serving ministers and congregations" was posed to the respondents. All ten respondents agreed that was the case with eighty percent of them agreeing strongly. The key point was not that the NTS should not plan the training, but that it should consult with the serving ministers or explain how things are done. Another policy question was about distance learning and contact learning practiced by the NTS as opposed to the Stellenbosch and Free State Ministerial Formations. Out of the respondents, ninety percent said that they disapprove of distance learning with one respondent not being sure. The question of distance learning was disapproved by the Northern Synod in 2003 and instead it was recommended that the URCSA ministerial formation be moved to the University of Pretoria, according to one of the informants. But the leadership of NTS reneged on the decision until they partially agreed to enter into it in 2011 when they entered into an agreement with the University of Pretoria while retaining eighty percent of students on distance learning. This fact shows that synod decisions may be manipulated by the officials without the synod realising or rescuing itself from it. 
Another question was posed to the respondents suggesting that members of the congregations have a high regard of what is offered at the NTS ministerial formation. Most of the respondents (eighty percent) disagreed with the postulation and only two agreed. Another related question was posed to suggest that university-based programmes primarily serve the interest of the academics and churches have little room to use them. Again, more than seventy percent of the respondents agreed with the statement and only one respondent disagreed. The position taken by the respondents towards the NTS ministerial formation is worrisome and it serves as a warning to the URCSA to take corrective steps as soon as possible.

\section{Juxtaposition of two related questions}

Two questions were asked separately, and their responses were juxtaposed to show the similarity and intensity of the problems the respondents experience with the NTS ministerial formation. The two questions concern the profile of URCSA ministers and what the respondents expected from the NTS students. With regard to the profile of URCSA ministers, the respondents listed the following: pastors with heart, managerial skills, awareness of church policies, theologically grounded, creative with sound judgement, reaching out to people, reformed oriented, visionary, accessible integrity, disciplined, loyal to the church, self-respect, reflexivity, trustworthiness, reliability and commanding respect. But responses to the similar question directed to evaluate the students suggested that there are some doubts as far as the NTS is concerned. Although there are overlapping similarities, graduates from NTS are expected to have sound knowledge of the polity of the church and its spirit, be prepared/exposed to serve in any situation, be transformative and visionary, be trained in true Reformed doctrine, be faithful with good examples, preach in context, lead congregations successfully, know Reformed Confessions/be truly reformed, be politically balanced, have strong moral leadership, and be socially and economically involved. Thus, the respondents are suggestive in terms of what they expect from NTS students while in the case of the URCSA ministers they affirm universal principles. 


\section{NTS programme and their expectations}

A related question was posed to the respondents as to whether NTS training meets their expectations. The previous question was focused on their expectation from NTS students and the second one was focused on the training as such. All ten respondents said that the NTS does not meet their expectations. One respondent said that the reason for that was because students' situations were not taken into consideration and contact session methods were suspect. At NTS training is done for the sake of training but not with set measurable objectives. Another respondent argued that NTS training does not meet his/her expectations because the seminar lacked resources while another said that sound knowledge is missing, and language is a barrier. Two respondents said NTS training did not connect with the congregations and that it was confusing. Another respondent blamed it on the fact that more than eighty percent of students were parttime and that NTS does not have a clear curriculum. The rest argued that the NTS training is suspect and they did not elaborate on what they meant by that.

Another related question was about the curriculum of NTS. The question posed was whether the curriculum takes social, economic and political realities of the country into account. One respondent said the NTS curriculum imposes a foreign world on students. Another one alleged that students come to NTS motivated and they leave demotivated. The fourth respondent complained that the curriculum has been shortened over the years at the expense of quality. The next respondent said the curriculum was irrelevant while five respondents admitted that they did not know what the curriculum contains. The last respondent made an assertion that students at NTS do not follow the URCSA programme but what interests them the most. This allegation is even more serious, and it needs further urgent investigation.

Respondents were asked to suggest how NTS ministerial formation may be structured. Some respondents saw the starting point of structuring the curriculum as consultation with congregations and ministers. A relevant curriculum is one that will empower ministers in their role as leaders in the congregations. It should reflect where the black community comes from and where it is heading to. It should start with the needs of the people 
after consultation. It should speak to the context of where people are. One respondent suggested that the curriculum should follow the present ministerial manual. Another response was that the traditional subjects such as church history, missiology, Old and New Testaments, practical theology, systematic theology and theological ethics should form the basis of the new curriculum while the other introduced the theological degrees up to Master of Theology in Practical Theology. The last one in this category suggested that the curriculum should have the welfare of the ministers at heart.

\section{Specific needs met by the NTS programme}

Respondents were asked to indicate the needs they thought the NTS programmes were meeting, despite their inadequacies. Three of the respondents mentioned that the programme licenses students for ministry and fills vacant positions in congregations. One respondent said that there is nothing to expect from unstructured contact sessions and the other two responded by saying that the NTS programme does not meet any needs. Two respondents referred to the qualifications offered there. One respondent said that there are high academic qualifications candidates can get through the NTS and that these help them to be called to the congregations while another respondent said that the qualifications give students the basic knowledge and skills, they need to prepare sermons. The last two respondents indicated that they were not aware of anything the NTS programmes are bringing to the church. On the Likert scale on whether NTS programmes prepare candidates for ministry, only forty percent of respondents said that the programmes fulfil specific needs while the other forty percent disagreed, and twenty percent of respondents were not sure. On another question as to whether NTS students have a sense of calling, forty percent disagreed, another forty percent were not sure and twenty percent agreed that they have a sense of calling.

Lastly, the respondents were asked whether they had any important suggestions for the NTS ministerial formation. Respondents felt that the NTS should work on the lost common identity of the seminary and congregations. The seminary should also prepare the students for the conditions prevailing in congregations. It should also arrange conferences for the ministers in order to help them in their professional work. They also 
suggested that consultation with ministers and congregations as well as effective communication should receive priority. The ministerial formation should also become a full-time training course for the URCSA ministers and academics who are members of the URCSA. They should be involved in the training. All serving ministers of the URCSA should undergo continuous workshops to equip them for their tasks in the changing environment.

\section{Conclusion and way forward}

The article set out to investigate the praxis in the URCSA Northern Synod based on the findings from a research project about the relationship between ministers and the staff of the NTS. It first interrogated the traditional approach to ministry training in the former Dutch Reformed Church in Africa and how it was transferred to the URCSA after the latter became the Uniting Reformed Church in Southern Africa - after the merger of the two churches in 1994. The study revealed a lack of consultation, coherence and communication between the staff of NTS and ministers as well as the agenda of decolonization of theological education in URCSA. The views of the ministers were used to make a proposal for change in the approach of the NTS to ministers for the effective emancipation of the church from coloniality.

But as part of a way forward, the researcher wishes to lay the foundation for discourse that may ensue from the article with insightful contributions of Van der Borght (2006) and Van der Beek (2006). Contributions are taken from the book edited by Van der Borght called Religion without Ulterior Motive and Shanks' (2005) book entitled Faith in Honesty. Van der Beek (2006) and Van der Borght (2006) advocate for a position where religion should never be used for instrumentalization to achieve any human agenda. The lesson one gains from this perspective is that Christianity or, for that matter, any theological argument should not be used to unfairly advance an ideology in defence of one's position. As God loves His people for no reason or gain, Christians too should avoid using theology in their discourse to advance their own ideological agenda. Van der Beek (2006: ii) and Van der Borght (2006:19) argue that the godliness for which Christians have been called to is to serve God for nothing as God loved them for no reason. The implication of this argument is that Christians should never fall in the 
temptation of protecting their own territory (neo-colonial interests) when they are corrected from their position. If this attitude of self-emersion in the reality of the poor and the marginalized is taken to heart, there will be progress in their service of God and humanity as they will be freed from self-gratification and temptation for grand-standing.

Shanks (2005) further warns against the Christian theology's overvaluation of the importance of "correctness" in any theological argument. What counts the most in any theological argument is radical "honesty" more than sincerity or frankness (Shanks 2005: iii). By radical "honesty", Shanks refers to sheer openness to the Other's point of view, which Shanks maintains is what the church should learn. Shanks (2005: iv) further argues that this theological "honesty" has three faces: 1) it stands totally opposed to banality, 2) manipulation and 3) the mere disowning of history. Radical "honesty", according to Shanks, means not lying to people holding a different view by being frank or evading their critical judgement. It is always open to learn from the encounter with the Other even if that means receiving their hostility and pains of being corrected to develop strengths of seeking out the truth but not possessing it (Shanks 2005: v).

The primary aim of this article has been to encourage sheer openness towards the staff of NTS in order to allow them to open up to a predominant point of view from the ministers of the congregations or churches. Although these views might challenge their sense of security and satisfaction with their programmes, these views should be taken into account in order for the NTS to open up to new challenges and to learn graciously from the outcasts of society. Theology is authentic only when it is in the service of the underside of history. In the context of URCSA the warning sounded by Biko (2004) and Bulhan (2015) should be taken to heart for any authentic liberating theological education. Black people should first go through a rigorous process of decolonising their minds before being co-opted in any multiracial education. The liberation of mind (being) should precede any discourse of education and much investment should be built into achieving that. A consciousness that liberates should be a prerequisite (Pityana 2012:11) of such education praxis. Steve Biko (in: Kritzinger 2008:102) rejected any development that stood for integration between the white and black. Black people had to discover first for themselves how they had been colonised and then emancipate themselves completely from any form of 
Western fossilisation. Relevant and authentic theological education for NTS has its foundation on the fight against colonialism (Sakupapa 2018) and is both necessary to eradicate coloniality or meta-colonialism (Bulhaan 2015), which continues to haunt the African mind (Biko 2004).

\section{Works consulted}

Assimeng, M. 1986. Saints and Social Structures. Legon: Ghana Publishing Corporation.

Belhar Confession. 1986. Dutch Reformed Mission Church. Belhar Centre Cape Town.

Biko, S. 2004. I write what I like. Ultra Lithu: Johannesburg.

Bosch, D. J. 1991. Transforming Mission: Paradigm Shifts in Theology of Mission. MaryKnoll: Orbis Books.

Bulhan, H. A. 2015. Stages of Colonialism in Africa: From Occupation of Land to Occupation of Being. Journal of Social and Political Psychology, 2015, Vol. 3(1), doi:10.5964/jspp.V3il.143

Calian, C. S. 2002. The Ideal Seminary: Pursuing Excellence in Theological Education. London: Westminster John Knox Press.

Cannell, L. 2006. Theological Education Matters: Leadership Education for the Church. Newburgh: EDCOT Press.

Changuion, L. \& Steenkamp, B. 2012. Disputed Land: The Historical Development of the South African Land Issue, 1652-2011. Pretoria: Protea Book House.

Costas. O. E. 1986. Theological Education and Mission. In Padilla C. R. New Alternatives in Theological Education, (pp 5-24). Oxford: Regnum Books.

Crafford, D. 1982. Aan God die dank. Pretoria: NG Kerboekhandel Transvaal.

Cronje, J. M. 1982. Born to Witness. Pretoria: NG Kerkboekhandel Transvaal. 
Du Toit, C. W. 2009. African Challenges: Unfolding Identities. Pretoria: Unisa Press.

Ela, J. M. 1986. African cry. Maryknoll: Orbis Books.

Elphick, R. 2012. The Equality of Believers: Protestant Missionaries and the Racial Politics of South Africa. Scottville: University of KwaZulu-Natal Press.

Fanon, F. 1963. The wretched of the Earth. New York: Ballantime.

Ferris, R. W. 1990. Renewal in Theological Education: Strategies for Change. Bill Gram Center: Wheaton College.

Foley, A. 2004. Language policy for higher education in South Africa: Implications and Complications. SAJHE. 18(1):57-71.

Grzelak, S. C. J \& Kinunda M. A. 2016. New Horizon in Theology and Challenges to Leadership in Africa. In A Journal of Catholic Reflection for Southern Africa. Vol 33 No 3 November 2016.

Hart, S. \& Mas-Colell, A. 1989. Potential, Value, and Consistency. Econometrica, 57(3):589-614.

Ilunga, B. 1984. Paths of Liberation: A Third world Spirituality. New York: Orbis Books.

Kgatla, S. T. 1988. Dutch Reformed Church mission in Northern Transvaal, 1865-1964: a critical evaluation of motives, goals and methods. Unpublished M.Th. Dissertation submitted to the University of South Africa. Pretoria.

Kgatla, S. T. 2018. Gender-based violence in post-apartheid South Africa. Unpublished paper read at SAMS annual conference. University of Pretoria.

Kgatla, S. T. 2019. A wild Donkey has no bands. Reach Publishers. Durban.

Kirkalby, A. 2005. Capturing the Soul: The Vhavenda and the Missionaries, 1870-1900. Pretoria: Protea Book House.

Kritzinger, J. N. J. 2010. Ministerial Formation Praxis in the Uniting Reformed Church in Southern Africa: In Search of Inclusion and Authenticity. Missionalia. 38(2):211-234. 
Kuyper, A. 1961. Calvinism. Grand Rapids: WB Eerdmans.

Longeway, J. L. (1990). The rationality of Escapism and Self-Deception.

Magesa, L. 1976. The Church and Liberation in Africa. Gaba Publications: Eldoret.

Molosi, K. \& Dipholo, K. (2016). Power Relations and the Paradox of Community Participation among the San in Khwee and Sehunong. Journal of Public Administration and Development Alternatives 1(1).

Moore. M. E M. 1991. Teaching from the Heart: Theology and Educational Method. Minneapolis: Augsburg Fortress.

Murphy, M. 2013. What did Marx Mean by Thesis Eleven? Social Theory Applied. [Online] http://socialtheoryapplied.com/2013/08/10/what-did-marxmean-by-thesis-eleven/ [Accessed: 20 June 2017].

Naidoo, M., 2012, "Ministerial formation of theological students through distance education", HTS Teologiese Studies/ Theological Studies 68(2). Art. \#1225, 8 pages, http://dx.doi.org/10.4102/hts.v68i2.1225

Ngugi wa Thiong'o, N. (1986). Decolonising the Mind: The Politics of Language in African Literature. London: J. Currey.

Noble, H, \& Smith, J. 2014. Evid Based Nurs. Vol.17, N0 1.

Padilla, C. R. 1986. New Alternatives in Theological Education (ed). Oxford: Begnum Books.

Saayman, W. A. 2007. Being Missionary Being Human: An Overview of the Dutch Reformed Ministry. Pietermaritzburg: Cluster.

Shanks, A. 2005. Faith in Honesty: The Essential Nature of Theology. Ashgate: Aldershot.

South African Students Movement [Online] http://www.sahistory.org.za/article/ south-african-student-movement-samsm [Accessed: 25/5/2017].

Uniting Reformed Church in Southern Africa, 2011. Manual for Ministerial Formation. Advent 2010. URCSA. Pretoria. 
Van der Beek, A. 2006. Religion Without Ulterior Motive. In Van der Borght, E A J G. Religion Without Ulterior Motive, (pp:7-20). Leiden: Brill.

Van der Borght, E. A. J. G. 2006. Religion Without Ulterior Motive Within the Reformed Tradition. In Van der Borght, E A J G. Religion Without Ulterior Motive, (pp 1-6). Leiden: Brill.

Wilhoit, J. 2000. Christian Education and the Search for Meaning. Baker Books: Grand Rapids.

Willis, D. \& Welker, M. 1999. Toward the Future of Reformed Theology: Tasks, Topics, Traditions. Grand Rapids: WB Eerdmans.

Worden, N. 2012. The Making of Modern South Africa: Conquest, Apartheid, Democracy. Oxford: Wiley-Blackwell. 